\title{
Analysis and Discussion on the Present Situation of the Teaching Reform in Colleges and Universities
}

\author{
Yuzhen Wang ${ }^{1, ~ a, ~ C h u n d i ~ Z h a o ~}{ }^{2, b}$ and Rengui Zhao ${ }^{3, c^{*}}$ \\ ${ }^{1}$ Chinese Medicine Materials College, Jilin Agricultural University, Changchun, P.R. China \\ ${ }^{2}$ Agricultural College, Jilin Agricultural University, Changchun, P.R. China \\ ${ }^{3}$ Mechanical \& Electrical Engineering College, ChangChun University of Science and Technology, \\ Changchun, P.R. China \\ a349835300@qq.com, b05395854@qq.com, ${ }^{\mathrm{c}}$ 2992807490@qq.com \\ *The corresponding author
}

Keywords: Colleges and universities; Teaching reform; Countermeasures

\begin{abstract}
Quality education has been the focus of education reform in our country in recent years, not only in primary and secondary schools to carry out the teaching reform; the university has also carried out the teaching reform. For colleges and universities, if we continue to use the traditional teaching methods, it will not be able to develop a comprehensive quality of talents for our country, for the teaching reform of colleges and universities is imperative. Of course, the reform cannot be done overnight, it needs to continue exploration. Therefore, in the teaching reform of colleges and universities in China is also facing a series of problems, only by solving these problems can promote the success of the reform. This paper focuses on the present situation of the teaching reform in colleges and universities in China and the corresponding countermeasures.

Twenty-first Centuries is called the century of talent, for the development of society and even the country, the talent is always essential. Colleges and universities as the training of talents of the University, its responsibility is more important. Talent does not only have a solid theoretical knowledge, but also should have a strong practical ability. But at the present stage, there are some problems in the teaching mode of our country, so the teaching needs to be reformed to make it more in line with the requirements of the times. However, there are still a series of problems in the teaching reform of colleges and universities in our country. The existence of these problems hinders the completion of teaching reform. For this reason, we should thoroughly study the reasons for the problems, so as to change the teaching mode, realize the new teaching methods, and cultivate more excellent talents for the social development of our country.
\end{abstract}

\section{Analysis on Present Situation of Teaching Reform in Colleges and Universities}

With the introduction of a series of documents on the reform of colleges and universities, the major colleges and universities also put on the agenda of teaching reform. But it is undeniable that many colleges and universities in the reform of the situation are not good, mainly reflected in the following three aspects.

Reform Goal Is not Clear. Through the relevant research found that there are some colleges and universities for the reform of the target are not clear enough. The goal of reform can be said to be the vane of the teaching reform in Colleges and universities. If you cannot clear the goal of reform, it will make the university cannot be the right way to reform the way forward. This will also affect the final results of its reform. The reason why the reform of the target is not clear, because the traditional teaching methods still continue to use, and even in the daily teaching of the University occupies a very important position. Many colleges and universities did not specify the clear goal of reform, which makes a lot of college teachers are only able to interpret the new curriculum. Through their own understanding of the curriculum teaching, so that in the classroom, the subject of teaching is still a teacher rather than a student. Students are not able to take the initiative to participate in the teaching reform, but only as a test of teaching reform. The introduction of the new curriculum reform in China made it clear that in the classroom, the main body should be students. 
Should let students actively participate in teaching, instead of the traditional "spoon feeding" passive teaching.

Teachers Lack of Reform Ideas. As the saying goes, "thought the decision action" to make teaching reform in Colleges and universities to succeed, then you need to reverse the teachers teaching ideas, so that it can grasp the new idea of the reform of teaching methods, so as to change the teacher's. However, many local university teachers still use the traditional teaching methods for teaching, although know the teaching reform, but not the actual action, it can be said that in a wait-and-see state, unable to understand the idea of reform. For example, superior to the relevant universities set the task of teaching, but the university administrators and teachers too much to superiors, just care about face job, but not the reforms carried out, leading to the teaching reform of out of order. Some colleges and universities in the process of teaching reform do not pay attention to the supervision and control of the establishment of institutions, which led to a lot of problems in the reform, has not been discovered in a timely manner.

Reform Practice and Objective Existence Deviation. When the reform is carried out in colleges and universities, it is required to refer to the new curriculum standards and the related ideas of quality education. However, there are some colleges and universities did not combine the new curriculum standards and quality education concept, and then analyze the actual situation of the university itself to complete the reform. In the process of reform, but the terms of the new curriculum standards mechanically, lead to the blindness of great reform. In addition, in the process of teaching just chose the new curriculum standard above requires the use of textbooks and reference materials, which makes the goal of teaching reform is not reached, the students cannot fully grasp related knowledge.

\section{On the Countermeasures of Teaching Reform in Colleges and Universities}

The university is the talent cultivation in China, the university should be aware of its existence in the process of reform of the problem, and to explore the corresponding countermeasures, clear objectives of the reform, to help teachers establish the idea of reform, reduce the deviation between the reform practice and the objectives of the reform.

Intensify the Propaganda of Teaching Reform. Many colleges and universities will be in the process of teaching reform is blind, because there is no enough publicity for teaching reform, nature cannot reflect the importance of teaching reform. Therefore, colleges should intensify the teaching reform of the publicity, especially for publicity for those who have achieved good results in the reform of case, can not only improve the college students for the teaching reform of confidence, can also play a certain role. Of course, the content of the teaching reform in Colleges and universities is mainly divided into two types: First, we should promote the teaching reform of the standard, and the standard is the introduction of the relevant provisions of the new curriculum standards. But also for each of the provisions of a detailed explanation, so that teachers and students can be comprehensive and in-depth understanding of the relevant content of teaching reform. Second, it should promote the successful teaching results, and draw on the successful experience. In addition, colleges and universities should put more energy into teaching reform, set up a special research group, supervise and manage the whole process of teaching reform. If we find that there is a deviation between the reform and the target, we should put forward the countermeasures in time, so that the whole reform can be launched smoothly.

Clear Idea of Reform. Colleges and universities should be used to undertake the task of teaching reform, to help teachers set up the idea of reform. First of all, colleges and universities should train teachers, so that it can understand the objectives of the reform, the content of reform and other key knowledge, so as to have a clear understanding of the reform, and then set up the idea of reform. Secondly, in the process of teaching reform in Colleges and universities, the real perpetrators are teachers themselves. Therefore, teachers should be under the guidance of the new curriculum standards, combined with the specific circumstances of their teaching courses to develop teaching content, but also through the reform of the in-depth summary of experience, improve teaching ability. 
Strengthening Cooperation between Colleges and Universities. The teaching reform of our country is not to say that the reform of a certain university, but all the universities in our country should carry on the teaching reform. Therefore, the University and the university can learn from each other through collaboration, so that the teaching reform in Colleges and universities can be successfully completed. First of all, colleges and universities in collaboration before, should understand their own reform process, to find its problems in the process of reform appeared, so through the collaboration between universities, can effectively avoid the emergence of other universities in the same type of problem. Secondly, the main body of teaching reform is the teacher, for this purpose, different college teachers should regularly exchange meetings or seminars. The reform of the achievements of teachers through their own teaching experience, the teachers can learn from other colleges and universities. Of course, for the same class of teachers can teach each other experience, for different classes of teachers can teach each other between the reform experiences. Teachers to communicate and exchange, to find a new direction of reform, put forward new countermeasures, and in the teaching practice of continuous optimization, so that teaching can be more fit the goal of reform and ideas.

\section{Conclusions}

There are many problems in the traditional teaching mode of China's colleges and universities, so that the training of talents cannot meet the requirements of talents in today's society, thus the teaching reform in Colleges and universities has become a hot spot. China on the introduction of a series of teaching reform of the document, the major colleges and universities are also exploring how to reform the teaching. In the process of teaching reform in Colleges and universities still exist many problems, these problems are mainly embodied in the reform goal is not clear enough, but college teachers cannot understand the idea of reform and reform direction and the reform idea is inconsistent. These problems have hindered the success of teaching reform in Colleges and universities, the universities should intensify the reform achievement propaganda, should help teachers to set up the idea of reform, strengthen exchanges and cooperation between the school and the school, work together to complete the teaching reform.

\section{References}

[1] Z. Li, Analysis on the present situation of teaching reform in colleges and universities, Countermeasures of the Research on the Practice and Teaching Research. (2015) 220.

[2] H.Y. Shi, F.F. Bu, Research on the present situation and countermeasures of physical education teaching reform in colleges and universities under the background of quality education, Sports World (Academic Edition). Vol. 06 (2016) 111-113.

[3] L. He, The present situation and countermeasures of the reform of analytical chemistry teaching contents in universities and colleges, Asia Pacific Education. Vol. 16 (2016) 83.

[4] J. He, Analysis on the present situation of art design teaching in colleges and universities and the countermeasures to explore the, Popular Literature and Art. Vol. 15 (2016) 216.

[5] Z.H. Zeng, X.J. Yin, Problems and countermeasures in the teaching reform of higher education in colleges and universities, Higher Architectural Education. Vol. 06 (2011) 10-14. 